\title{
COMPARATIVE ANALYSIS OF THE SELECTED LAND CONSOLIDATION PROJECTS
}

\author{
Atkoceviciene Virginija, Jukneliene Daiva, Valciukiene Jolanta, Orechovaite Diana \\ Vytautas Magnus University Agriculture Academy (Lithuania)
}

\begin{abstract}
Land consolidation is an important stage for agriculture and rural development. During the land reform, parcels of irrational size and shape were formed, which became difficult to cultivate efficiently. In essence, land consolidation projects must primarily be developed in areas with large, viable farms, and land parcels forming land holdings are not compact, distant from each other and from centers. Land consolidation projects have been under development for many years, but it is appropriate to pay attention to the expediency of implemented projects. Land consolidation goals and procedures vary from country to country, as the development of this procedure in each country is determined by historical trends, culture, traditions and land consolidation legislation. Many of those who have analyzed this topic emphasize the need for consolidation, but it is very important that landowners understand the importance of this process and make sure of its opportunities and benefits. Land consolidation must be designed so that the benefits of the project are higher than the results of the conversion works before the project. The purpose of this article is to compare land consolidation projects which were prepared in different areas of Lithuania. Two objects of the research in which land consolidation projects had been carried out and implemented in 2013 were selected, where the number of sites in units decreased: $41.8 \%$ in one project and $28 \%$ in the other. Changes in parcel configuration were also noticeable, when in one of the projects analyzed even 92 percent of land parcels have become regular - close to rectangular - shapes. The average size of land parcels in this project increased from 5.32 ha to 9.14 ha.
\end{abstract}

Key words: land parcel, consolidation, land users, private and state land.

\section{Introduction}

During the land reform in Lithuania, where the ownership rights were restored, the focus was on returning land rather than forming farms, so landowners or land users now have to cultivate land in several irregularly shaped and distant lands.

In order to improve the conditions for agricultural land use and cultivation, in many European countries, land consolidation has been underway for almost 100 years, with the aim of completing complex land reparcelling, changing land parcels' boundaries and location according to a land consolidation project for a particular area.

From land consolidation processes in Lithuania, it is expected that they will help to solve the problems of abandoned lands, as well as increase the productivity, efficiency and competitiveness of the agricultural sector, and at the same time will ensure the balanced development of rural areas as well as promote the creation of jobs in rural areas, will contribute to environmental protection and management of natural resources (Dapkus, 2008).

In 2008, the Government of the Republic of Lithuania approved the National Land Consolidation Strategy, the main objective of which is to ensure rational use of land and infrastructure development, increase the competitiveness of farms, protect the environment, foster cultural heritage and landscape and develop alternative activities (Lietuvos, 2018).

In order for farmers to compete successfully on the European Union market, it is necessary to provide for new land management measures that help to transform small and scattered plots of land into rational, more efficient land use. For this purpose, land consolidation is needed (Gauděšius, 2010).

Rural development, consolidation projects are mainly carried out in Germany, the Netherlands, France, Belgium, Luxembourg, Austria and Switzerland, as well as in Finland, Norway and Sweden (Vitikainen, 2004).

In Denmark, land consolidation is carried out on a voluntary basis by landowners and a democratic approach to land parcel conversion. In Germany, this process is more regulated by the relevant public authorities. However, in many other countries in central and eastern Europe, especially where land consolidation has only recently begun, there are more areas than a simple land conversion. Other landrelated issues related to environmental protection, infrastructure and the improvement of living conditions in rural areas are also addressed concerning land management issues (Dapkus, 2008).

After conducting the research of land consolidation projects in Central and Eastern Europe, P.Aleknavičius (2009) presents four different levels of land consolidation projects: 
Comprehensive land consolidation. This consolidation includes key works such as rural renewal, improvement of road infrastructure, reconstruction and construction of land reclamation systems, improvements in environmental and natural resource use, development of social infrastructure.

Ordinary land consolidation. The main optimization works of land parcels in such projects are the redevelopment of land parcels, improvement of form, development while purchasing land from state or land owners. These works can be combined with the restoration of infrastructure and drainage.

Voluntary group consolidation. These projects are similar to simplified land consolidation, but landowners participate in these projects only on a voluntary basis.

Individual land consolidation. It is a random and individual spread of land parcels initiated by private farmers.

The most effective tool for consolidating agricultural development is comprehensive land consolidation, although other ways can also bring benefits (Martinkus, 2010).

In order to form rational land holdings and improve their structure, pilot land consolidation projects have been started in Lithuania since 2000, and the first legal actions were implemented only in 2004 when the Seimas of the Republic of Lithuania adopted amendments to the Land Law (Selmone et al., 2016).

The primary objective of the first pilot project was to develop the most convenient use of arable land for 392 ha. The consolidation project has improved the value of the land parcels by changing their configuration and designing new access roads. It has been proven that land consolidation improves local agricultural structures and increases the economic stability of family farms within the design area. In 2002, a second Danish-Lithuanian pilot project was launched: "Land consolidation - an instrument for sustainable rural development". This project also sought to achieve more goals, including the promotion of local initiatives and the establishment of a related rural development strategy (Daugalienè, 2003).

These pilot land consolidation projects have shown that land consolidation can be a tool for achieving sustainable rural development, when through spatial planning processes agricultural structure and infrastructure are being improved, combining and meeting public interests, contributing to the environment and the countryside, cultural heritage, conservation and upholding of values (Naujokaitytè, 2017).

The National Land Service under the Ministry of Agriculture has confirmed that the land consolidation project will give landowners and the local community priority to receive external funding from other European Union Structural Funds to achieve the anticipated improvements, such as renovation of drainage systems, the local road network. Currently, the critical situation is with local (outdoor) roads. Farmers drive beyond the boundaries of their neighbors, although the road network is planned in the land reform plans (Pasakarnis and Maliene, 2010).

In general, 14 land consolidation projects were implemented in Lithuania from 2005 to 2007. The projects were organized in four Lithuanian counties: Marijampolè, Panevėžys, Taurage and Telšiai (Čepkauskaite, 2016). In 2007-2013, 39 land consolidation projects were completed in 18 municipalities (Naujokaitytė, 2017).

After this period, following an overview of these projects, it was considered most convenient to develop land consolidation projects in larger areas where more land users would be involved, thus creating preconditions for better land parcel design. Unfortunately, it was not possible to achieve optimal results in almost all land consolidation projects, as these projects could not include state land plots due to legislative changes (Aleknavičius et al., 2016).

Currently, i.e. during the period 2014-2020, 8 land consolidation projects are being prepared.

\section{Methodology of research and materials}

The aim of the article is to compare land consolidation projects carried out in Lauksargiai cadastral area of Tauragė district and Upyna cadastral area of Telšiai district.

The following tasks are aimed at achieving the goal:

1. To perform an analysis of the prepared two consolidation projects.

2. To identify and evaluate the expediency of land consolidation project preparation.

The article was prepared by the method of analysis of legal acts and scientific literature. The results of the statistics are presented on the basis of methods of collection, systematization, processing, logical analysis and generalization.

The object of the work - two land consolidation projects carried out and implemented in 2013 in Lauksargiai cadastral area of Taurage district and Upyna cadastral area of Telšiai district, the purpose 
of which is to find out the expediency of preparation of these projects. Research data - statistics of State Land Fund.

\section{Discussions and results}

\subsection{Solutions for land consolidation project in Tauragè district Lauksargiai cadastral area}

The main mission and goal of the consolidation project of the Lauksargiai cadastral area of Taurage district is to re-plan land holdings by changing land parcels and using free state land in order to make them comfortable for farming (Figure 1).

The selected area is $16 \mathrm{~km}$ from the town of Tauragè. The area consists of three arrays - a mythological object, which covers a part of a private parcel, is enclosed in the project area. The largest part of the project area includes intensive agricultural activity with a priority of cattle-breeding - crop production in land of good economic activity, and in the south-eastern part of the territory existing group IV forests, among which are not used agricultural land, which is suitable for planting forests.

Agricultural land in the project area is $408.08 \mathrm{ha}$, of which arable land -400.20 ha, gardens $-0.37 \mathrm{ha}$, meadows and natural pastures -7.50 ha, forests 54.56 ha, waters -2.07 ha and the other land -59.17 ha.

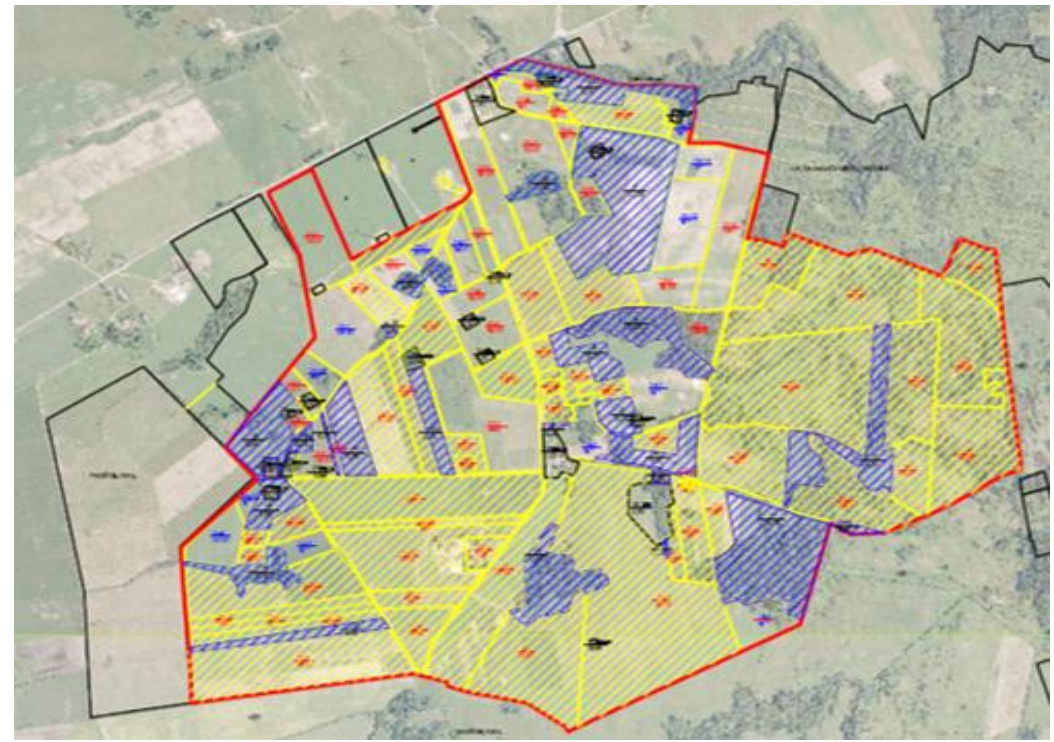

Figure 1. Taurage district Lauksargiai cadastral area before the project (Tauragès, 2013)

31 person participated in the preparation of the consolidation project. The total area of the territory is 521.02 ha, in which 98 plots of land have been formed and legalized, including 26 state land parcels, which occupy 86.3495 ha. The other 72 parcels (434.6705 ha) are owned by the citizens of the Republic of Lithuania. State land parcels are located throughout the project area between private land parcels. Some of them are of irrational and irregular configurations. The average parcel area is $3.32 \mathrm{ha}$. In order to form a land of rational size and form for agricultural and forestry land, this area was restructured without prejudice to the boundaries of the area selected for the project. The area selected for the project was complexly reconfigured by joining, dividing, separating and redistributing land parcels, anticipating their location and boundaries. The solutions for the consolidation project are presented in Figure 2. 


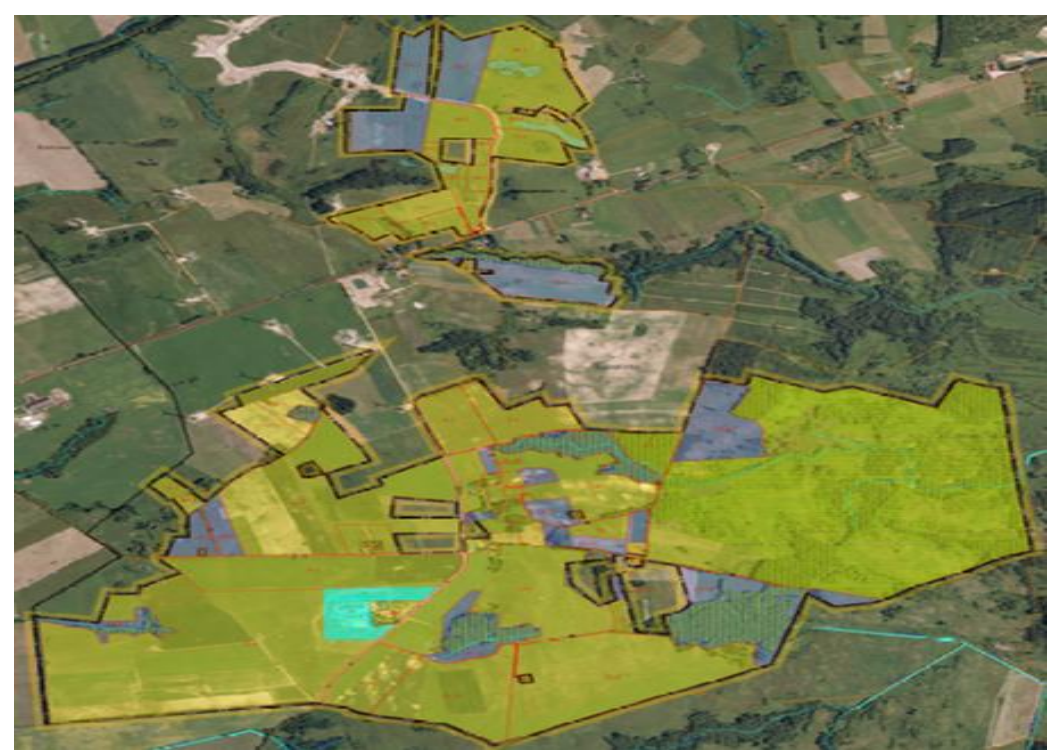

Figure 2. Taurage district Lauksargiai cadastral area after the project (Taurages, 2013).

The results of the analyzed land consolidation project are presented in Table 1.

Table 1.

Indicators of land consolidation project in Taurage district Lauksargiai cadastral area

(Author's, Source, Taurage, 2013)

\begin{tabular}{|c|c|c|c|c|c|c|c|c|c|}
\hline Situation & $\begin{array}{c}\text { The area } \\
\text { of LC } \\
\text { project } \\
\text { territory }\end{array}$ & $\begin{array}{c}\text { Number } \\
\text { of } \\
\text { private } \\
\text { land } \\
\text { owners }\end{array}$ & $\begin{array}{c}\text { Number } \\
\text { of land } \\
\text { parcels }\end{array}$ & $\begin{array}{c}\text { of } \\
\text { these - } \\
\text { state } \\
\text { land } \\
\text { parcels }\end{array}$ & $\begin{array}{c}\text { Average } \\
\text { parcel } \\
\text { size }\end{array}$ & \multicolumn{2}{|c|}{$\begin{array}{c}\text { The shape of } \\
\text { the parcel is } \\
\text { close to a } \\
\text { rectangle }\end{array}$} & \multicolumn{2}{|c|}{$\begin{array}{c}\text { The form of the } \\
\text { parcel is } \\
\text { different, } \\
\text { irregular }\end{array}$} \\
\cline { 5 - 10 } & & & & $\begin{array}{l}\text { number } \\
\text { in units }\end{array}$ & $\%$ & $\begin{array}{l}\text { number } \\
\text { in units }\end{array}$ & $\%$ \\
\hline $\begin{array}{l}\text { Before the } \\
\text { reparcelling }\end{array}$ & 521.02 & 31 & 98 & 26 & 5.32 & 33 & 34 & 65 & 66 \\
\hline $\begin{array}{l}\text { After the } \\
\text { reparcelling }\end{array}$ & 521.02 & 31 & 57 & 19 & 9.14 & 9 & 16 & 48 & 84 \\
\hline
\end{tabular}

After the land consolidation project, the number of landowners remained unchanged (31). The number of land parcels decreased by 41.8 percent (from 98 plots to 57). Of the 26 state land parcels, 19 remained, $27.8 \%$ of them fell. Average land parcel size increased by more than 41 percent (from 5.32 to 9.14 ha). Regular forms of land parcels fell to 16 percent and irregular parcels increased to 84 percent.

\subsection{Solutions for land consolidation project in Upyna cadastral area of Telšiai district}

The preparation of the land consolidation project in Upyna cadastral area of Telšiai district was expected to have a positive long-term impact on agricultural activity and faster economic development of competitive farms. Provision was made for a positive impact on the soil of consolidated and designed parcels of land of regular shape, as the quality of the parcels would be improved by adapting crop rotations. Intensive agricultural activity is foreseen in the project area (Figure 3). 

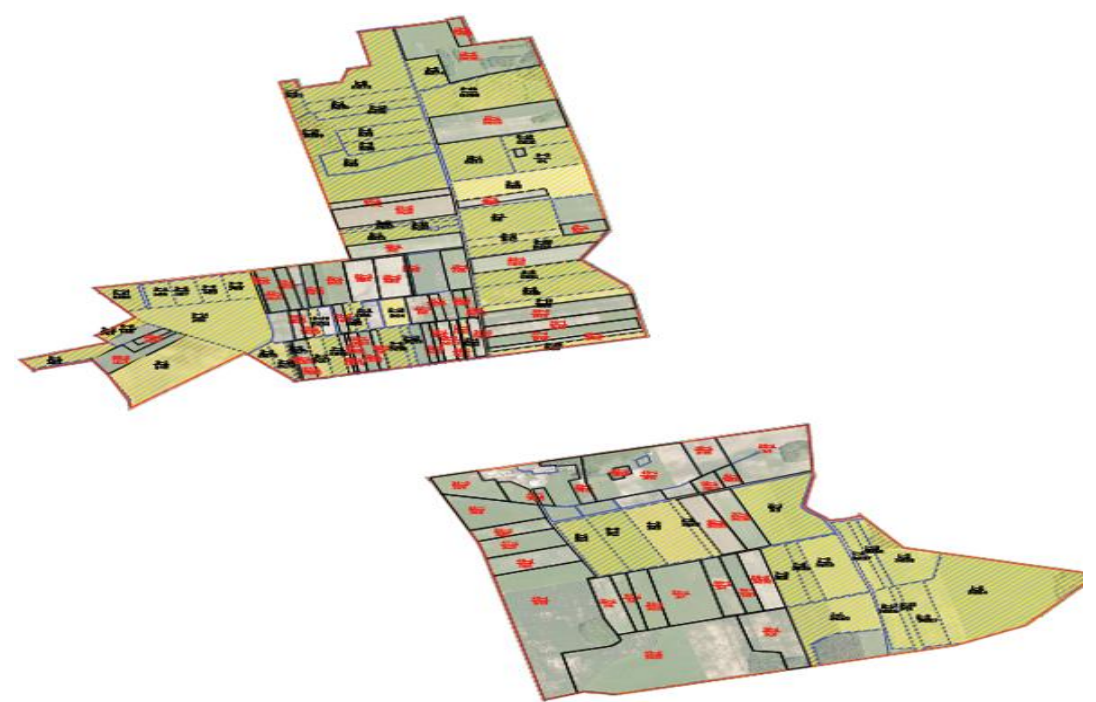

Figure 3. Territory of the planned land consolidation project in Upyna cadastral area of Telšiai district (Telšiai, 2013)

75 people participated in the project. The area occupied 695.19 ha, of which 11 land parcels belonged to the state. The area of state land is 10.65 ha. The area selected for the project was complexly reconstructed by joining, dividing, separating and redistributing land plots, anticipating their location and boundaries (Figure 4).

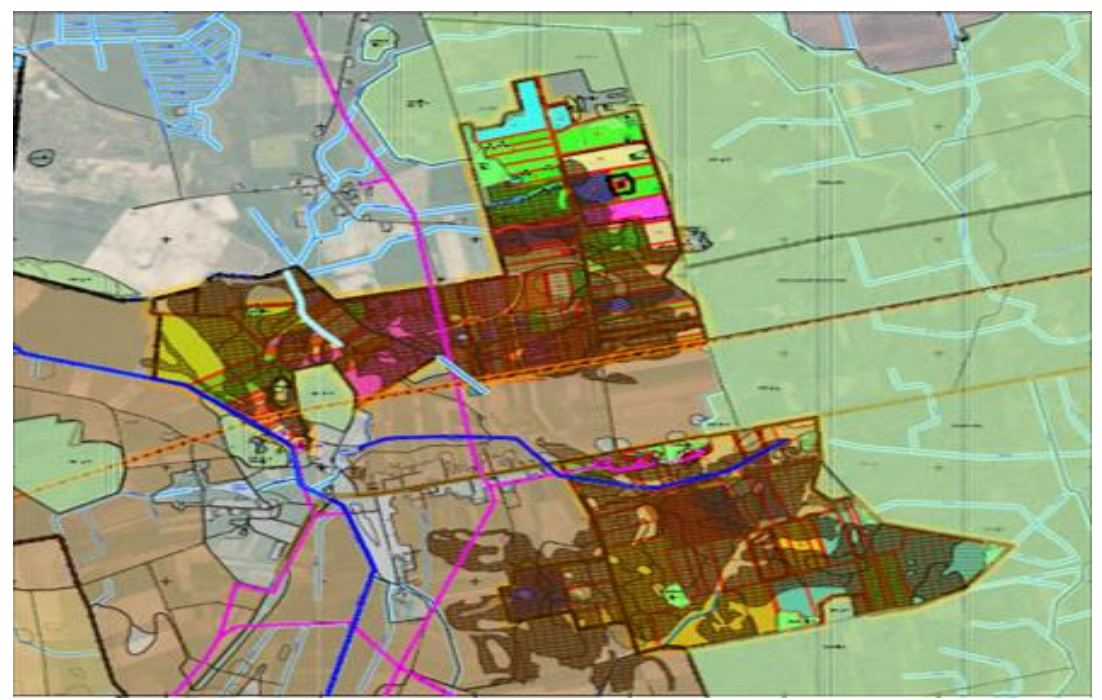

Figure 4. The Upyna cadastral area of Telšiai district after the consolidation project (Telšiai, 2013)

The land consolidation project did not change the number of landowners. The number of land parcels fell from 161 to 116 parcels, i.e. 28 percent. State land fell by only 1 parcel (10 percent). The average size of the land parcel before the land consolidation project was 4.32 ha and after the project increased to 6.00 ha. Before the conversion $63 \%$ of parcels were classified as close to the rectangle, and 37 percent were of another irregular shape. After the transformation - most of the parcels were enlarged and their form was close to the rectangle, such parcels constituted 92 percent. Only 8 percent of the irregular land parcels remained. Changes in parcel configuration are presented in Table 2. 
Table 2

Indicators of the land consolidation project in Upyna cadastral area of Telšiai district (Author, source,

Telšiai, 2013)

\begin{tabular}{|c|c|c|c|c|c|c|c|c|c|}
\hline Situation & $\begin{array}{c}\text { The area } \\
\text { of LC } \\
\text { project } \\
\text { territory }\end{array}$ & $\begin{array}{c}\text { Number } \\
\text { of private } \\
\text { land } \\
\text { owners }\end{array}$ & $\begin{array}{c}\text { Number } \\
\text { of land } \\
\text { parcels }\end{array}$ & $\begin{array}{c}\text { of these } \\
- \text { state } \\
\text { land } \\
\text { parcels }\end{array}$ & $\begin{array}{c}\text { Average } \\
\text { parcel } \\
\text { size }\end{array}$ & \multicolumn{2}{|c|}{$\begin{array}{c}\text { The shape of } \\
\text { the parcel is } \\
\text { close to a } \\
\text { rectangle }\end{array}$} & \multicolumn{2}{|c|}{$\begin{array}{c}\text { The form of } \\
\text { the parcel is } \\
\text { different, } \\
\text { irregular }\end{array}$} \\
\cline { 5 - 10 } & & & & & & $\begin{array}{c}\text { Number } \\
\text { in units }\end{array}$ & $\%$ & $\begin{array}{c}\text { Number } \\
\text { in units }\end{array}$ & $\%$ \\
\hline $\begin{array}{l}\text { Before the } \\
\text { reparcelling }\end{array}$ & 695.19 & 75 & 161 & 11 & 4.32 & 101 & 63 & 60 & 37 \\
\hline $\begin{array}{l}\text { After the } \\
\text { reparcelling }\end{array}$ & 695.19 & 75 & 116 & 10 & 6.00 & 103 & 92 & 9 & 8 \\
\hline
\end{tabular}

\subsection{Summary of the results of land consolidation projects}

Following the analysis of two land consolidation projects, the following evaluations of the expediency indicators of the preparation of these projects were identified, assessing the indicative project development objectives (indicators) (Table 3 ).

Table 3

Evaluation of expediency indicators of completed land consolidation projects (compiled by authors).

\begin{tabular}{|c|c|c|}
\hline Indicators & Cadastral area Lauksargiai & Cadastral area Upyna \\
\hline $\begin{array}{l}\text { 1. To form parcels } \\
\text { of rational size and } \\
\text { form for } \\
\text { agricultural and } \\
\text { forestry land. }\end{array}$ & $\begin{array}{l}\text { There were } 98 \text { land parcels before } \\
\text { the project, } 26 \text { of which belonged } \\
\text { to the state. In the course of the } \\
\text { consolidation project, } 57 \text { private } \\
\text { parcels of land were formed. State } \\
\text { ownership remained }-19 \text { parcels. } \\
\text { But irregular land parcels } \\
\text { increased by } 18 \text { percent. }\end{array}$ & $\begin{array}{l}\text { Before the consolidation project there were } 161 \\
\text { private parcels of land, including } 11 \text { state land } \\
\text { parcels. After the project } 116 \text { land parcels were } \\
\text { formed. } 10 \text { land parcels have remained in state } \\
\text { ownership. During this project, the regular parcels of } \\
\text { land increased by } 29 \text { percent. }\end{array}$ \\
\hline $\begin{array}{l}\text { 2. To enlarge land } \\
\text { holdings and } \\
\text { improve } \\
\text { brevity. }\end{array}$ & $\begin{array}{l}\text { These requirements are met by } \\
\text { two farmers' farms. There were } 33 \\
\text { parcels of land in the area of } \\
201.45 \text { ha before the conversion, } \\
\text { and after the conversion }-11 \\
\text { parcels in the area of } 201.45 \text { ha. } \\
\text { By restructuring } 26 \text { land parcels } \\
\text { with an area of } 86,349 \text { hectares } \\
\text { were converted into } 19 \text { land } \\
\text { parcels with a total area of } 86.28 \\
\text { ha. }\end{array}$ & $\begin{array}{l}\text { One owner owned } 9 \text { parcels of land, of which } 5 \\
\text { parcels were combined with two other parcels of land } \\
\text { owned by both farmers. Compact land parcel of } \\
28.07 \text { ha and } 43.22 \text { ha were designed. } \\
\text { Two landowners owned } 11 \text { land parcels with a total } \\
\text { of } 88.81 \text { hectares of land before design. } 5 \text { land } \\
\text { parcels with an area of } 89.63 \text { ha were designed for } \\
\text { them. } \\
6 \text { land parcels were owned by two spouses prior to } \\
\text { design, with an area of } 22.13 \text { ha. One of the spouses } \\
\text { owned } 22 \text { more parcels with an area of even } 102.30 \\
\text { ha. } \\
\text { After the project, } 4 \text { land parcels of } 63.59 \text { ha of } \\
\text { common ownership have been designed and } 8 \text { parcels } \\
\text { of land of } 63.07 \text { ha were designed for one of the } \\
\text { spouses. }\end{array}$ \\
\hline $\begin{array}{l}\text { 3. To reduce } \\
\text { distances between } \\
\text { parcels of land on } \\
\text { farm land. }\end{array}$ & $\begin{array}{l}3 \text { land parcels belonging to } \\
\text { farmers were formed around a } \\
\text { farm center, which contains the } \\
\text { main farmer's buildings, } \\
\text { machinery and equipment. } \\
\text { Another } 5 \text { owners have achieved } \\
\text { the best distance reduction. }\end{array}$ & $\begin{array}{l}\text { In the land consolidation project, the key solutions } \\
\text { were not foreseen in terms of the reduction of } \\
\text { distances between land parcels on the farm land. }\end{array}$ \\
\hline
\end{tabular}


Continuation of Table 3

\begin{tabular}{|c|c|c|}
\hline Indicators & Cadastral area Lauksargiai & Cadastral area Upyna \\
\hline $\begin{array}{l}\text { 4. To create the } \\
\text { right rural } \\
\text { infrastructure. }\end{array}$ & $\begin{array}{l}\text { The road network was analyzed } \\
\text { during the design. The road was } \\
\text { rebuilt to the extent necessary to } \\
\text { consolidate land parcels and } \\
\text { provide access roads to each } \\
\text { formed parcel and cemetery. }\end{array}$ & $\begin{array}{l}\text { A number of roads have been redesigned to improve } \\
\text { the road network, making them more convenient for } \\
\text { passing agricultural machinery, and instead of the } \\
\text { 4-meter-wide field road, a } 10 \text {-meter-wide road with a } \\
\text { length of } 709 \text { meters was designed. More convenient } \\
\text { passes to land parcels were designed, } 81 \text { meters long } \\
\text { and } 6 \text { meters wide. To make it easy to get to the } \\
\text { parcel, a road of } 81 \text { meters long and } 6 \text { meters wide } \\
\text { was designed for another farmer. }\end{array}$ \\
\hline $\begin{array}{l}5 . \quad \text { To identify } \\
\text { regulatory } \\
\text { restrictions on } \\
\text { land use. }\end{array}$ & $\begin{array}{l}\text { The area is classified as a } \\
\text { component of the natural } \\
\text { framework - geo-geological } \\
\text { divisions of regional importance. } \\
3 \text { servitude roads were designed } \\
\text { for land parcels. }\end{array}$ & $\begin{array}{l}\text { Formed servitudes: road servitude - right to drive } \\
\text { (dominant object); road servitude - the right to drive } \\
\text { vehicles (serving object); servitude, right to build } \\
\text { underground, ground communications (serving } \\
\text { object). } \\
\text { It is planned to build a gas pipeline, for which a } \\
\text { servitude (serving object) to construct a trunk gas } \\
\text { pipeline and its facilities was established, as well as a } \\
\text { servitude (serving object) the right to serve } \\
\text { underground, ground communications. } \\
\text { Specific land use conditions are defined: road } \\
\text { protection zone, protection zone of power lines, } \\
\text { territory of immovable cultural property and } \\
\text { protection zones, land parcels with state-owned land } \\
\text { reclamation systems and equipment, protection zones } \\
\text { of main gas pipelines and pipelines and their } \\
\text { facilities, protection zones of surface water bodies } \\
\text { and coastal protection belts, forest use restrictions, } \\
\text { soil protection and pipeline protection zones. }\end{array}$ \\
\hline $\begin{array}{l}\text { 6. To improve the } \\
\text { territory's } \\
\text { recreational, rural } \\
\text { tourism and } \\
\text { aesthetic } \\
\text { resources. }\end{array}$ & $\begin{array}{l}\text { The area selected for the project is } \\
\text { used for intensive agriculture, so } \\
\text { there are no recreational areas. }\end{array}$ & $\begin{array}{l}\text { The land consolidation project did not foresee } \\
\text { solutions for territorial recreation, rural tourism. }\end{array}$ \\
\hline $\begin{array}{l}\text { 7. To implement } \\
\text { other objectives } \\
\text { of agriculture, } \\
\text { rural development } \\
\text { and environment } \\
\text { policy. }\end{array}$ & $\begin{array}{l}\text { Two owners of one parcel of land } \\
\text { on forest parcels (situated } \\
\text { between forests) wanted to plant a } \\
\text { forest. An area of } 81.33 \text { hectares } \\
\text { is planned to be planted with } \\
\text { forest (from the formed area of } \\
125.60 \text { hectares). The other two } \\
\text { owners of the same parcel wished } \\
\text { to expand the area of the } \\
\text { farmstead, as farmers anticipate } \\
\text { the development of their farm. }\end{array}$ & $\begin{array}{l}\text { The overall physical state of land reclamation in the } \\
\text { land consolidation project is good, therefore no } \\
\text { reconstruction of land reclamation systems and } \\
\text { equipment is foreseen. No new power lines will be } \\
\text { provided while reconstructing land parcels. }\end{array}$ \\
\hline
\end{tabular}

Summarizing the expediency of the 2 land consolidation projects analyzed, it can be stated that the land consolidation projects in Taurage district Lauksargiai and in Telšiai district Upyna cadastral areas were aimed at implementing territorial planning solutions. Implementing the solutions of these projects, the basic economic benefits of improving the configurations of the sites, their conciseness and tightness are obtained by transport costs. Significant economic benefits will also be felt by the owners of the parcel intended to be planted with forest, since instead of several forest planting projects, only one will be required. Agricultural activity will reduce environmental pollution by reducing the number of kilometers traveled and forest planting. 


\section{Conclusions and proposals}

1. According to formed land parcels of rational size and form, it can be stated that the average size of the parcel of land in Lauksargiai cadastral area increased from 5.32 to 9.14 ha. But in this area, after the consolidation project, land parcels of irregular shape (18 percent) increased. The area of the land parcel before the land consolidation project was 4.32 ha in the area of the Upyna cadastral area, and after the project increased to $6.00 \mathrm{ha}$. In this area, the number of land parcels of regular shape has increased (29\%).

2. In the Taurage district Lauksargiai cadastral area, the number of parcels of land was 98 before the land consolidation project. After the land consolidation project, the number of parcels decreased to 57 plots (41.8\%). The number of land parcels in the Upyna cadastral area of Telšiai district was 161 , and after the project implementation decreased to 116 parcels $(28 \%)$.

3. The land consolidation project in Lauksargiai cadastral area has achieved the best result of distance reduction for 8 landowners. And in the area of Upyna cadastre, the issue of distance reduction between land parcels on the holding was not decided.

4. Better results had been achieved in the road network management of Upyna cadastral area consolidation project. Analysis of both projects showed that land use restrictions were taken into account and land easements were established. The cadastral areas examined are not included in recreational areas.

5. For the implementation of other objectives of agriculture, rural development and environment policy, the land consolidation project in Lauksargiai has formed the area of land for the establishment of the forest and it is planned to expand the place of the homestead, anticipating the development of the farm. These issues were not solved in the Upyna land consolidation project.

6. Based on the results of the analysis carried out, it can be stated that in order to compete successfully in agriculture, the consolidation and enlargement of parcels as well as the purposeful complex restructuring of the territory are of great importance, not only to form land of rational size and form, but also to develop agricultural, rural development land management projects together ensuring the rational use of farm land, taking into account farm activities and environmental protection requirements, as well as creating the necessary rural infrastructure and improving recreational and rural tourism resources. All this would increase the attractiveness of rural areas.

\section{Reference}

1. Aleknavičius A., Aleknavičius M., Aleknavičius P. (2016) Didelių ūkiu žemės valdų optimizavimas [Optimization of land holdings on large farms]: Žemès ūkio mokslai. Nr. 4. 23 p. (In Lithuanian)

2. Aleknavičius, A. (2009). Possibilities for rural development implementing land consolidation projects in Lithuania: Rural development 4, p. 2-6.

3. Čepkauskaitè R. (2016) Radviliškio rajono Šaukoto kadastro vietovès žemės konsolidacijos projekto analizė ir vertinimas [Analysis and Evaluation of the Land Consolidation Project of the Šaukotas Cadastral Area of Radviliškis District] Iš: Mokslo darbai. ASU, 26 p. (In Lithuanian)

4. Dapkus R. (2008). Žemès konsolidacija kaip vienas esminių kaimiškujų regionų subalansuotos plètros veiksniu [Land consolidation as a key factor for sustainable development in rural areas]: Vadybos mokslaskaimo verslų ir jų infrastruktūros plètrai: mokslo darbai, p. 54-61. (In Lithuanian)

5. Daugalienè V. (2003) Racionali žemènauda - kelias ị ūkininkavimo sèkmę [Rational land use - path to farming success], Interactive, Accessed in 2019-03-01 (http://zum.lrv.lt/lt/naujienos/racionali-zemenaudakelias-i-ukininkavimo-sekme). (In Lithuanian)

6. Gaudèšius R. (2010) Plungès rajono, Šateikių kadastro vietovès žemės konsolidacijos projekto analizè ir ivertinimas [Analysis and Evaluation of Land Consolidation Project in Plunge District, Šiauliai Cadastral Area], ASU. (In Lithuanian)

7. Act of Government of Republic of Lithuania, January 23, 2008, No. 81, (2019) „Dèl nacionalinès žemès konsolidacijos strategijos patvirtinimo" [Concerning the adoption of the National Land Consolidation Strategy] (recast from 2010-09-03). (In Lithuanian)

8. Martinkus M. (2010). Žemès konsolidacija Lietuvoje ir Europoje [Land consolidation in Lithuania and Europ]: Mokslo darbai, ASU, 30 p. (In Lithuanian)

9. Naujokaitytė G. (2017) Žemès ūkio paskirties žemès naudojimas Šakių rajono savivaldybèje iggyvendinto žemès konsolidacijos projekto teritorijoje [Use of agricultural land of implemented consolidation project in Šakiai district municipality ]: Mokslo darbai. ASU, 11 p. (In Lithuanian)

10. Pašakarnis G., Malienè V. (2010) Towards sustainable rural development in Central and Eastern Europe: Applying land consolidation: Land Use Policy, 8 p. 
11. Selmonè E., Dapkienè M., Valčiukienè J. (2016) SWOT analysis of land consolidation projects in western Lithuania: International scientific journal, Volume 4. $75 \mathrm{p}$.

12. Tauragès apskrities Tauragès rajono savivaldybės Lauksargių seniūnijos Lauksargių kadastro vietovès Gilandviršių, Griežpelkių I, Griežpelkių II kaimų ir jų dalių žemės konsolidacijos projekto sprendiniai. (2013) Tekstinè ir grafinè dalys. Tauragè [Solutions of the land consolidation project of the villages of Gilandviršiai, Gigorpelkiai I, Geležpelkiai II in the Lauksargiai cadastre area of Taurage district municipality. (2013) Textual and Graphic Parts. Taurage]. (In Lithuanian)

13. Telšių apskrities Telšių rajono savivaldybės Upynos seniūnijos Upynos kadastro vietovės Užpelkių, Endrietiškių, Upynos kaimų ir jų dalių žemès konsolidacijos projekto teritorijos sprendiniai. (2013). Tekstinè ir grafinè dalys. Luokè. [Solutions of the land consolidation project for the Upyna cadastral area of the villages Užpelkių, Endrietiškių, Upynos in Telšiai district municipality. (2013). Text and graphic parts. Luoke]. (In Lithuanian)

14. Vitikainen A. (2004) An Overview of Land Consolidation in Europe: Helsinki University of Technology Institute of Real Estate Studies, Finland. 32 p.

15. Žemès konsolidacija - svarbi kaimo plètros dalis [Land consolidation is an important part of rural development], (2006) Interactive, Accessed in 2019-03-30. (http://zum.lrv.lt/lt/naujienos/zemeskonsolidacija-svarbi-kaimo-pletros-dalis) (In Lithuanian)

\section{Information about authors}

Virginija Atkocevičienė, Lecturer.Vytautas Magnus University, Institute of Land Use Planning and Geomatics, Faculty of Land and Water Management. Address: Universiteto str. 10, LT - 53361 Akademija, Kaunas, Lithuania. Ph. (37) 752372. e-mail: virginija.atkoceviciene@gmail.com, Fields of interest: land-use management, development of rural areas.

Jolanta Valčiukienė. Associate professor, doctor. Vytautas Magnus University, Institute of Land Use Planning and Geomatics, Faculty of Land and Water Management. Address: Universiteto str. 10, LT - 53361 Akademija, Kaunas, Lithuania. Ph. (37) 752372. e-mail: valciukienejolanta@gmail.com, Fields of interest: land-use management, spatial planning.

Daiva Juknelienė. Lecturer. Vytautas Magnus University, Institute of Land Use Planning and Geomatics, Faculty of Land and Water Management. Address: Universiteto str. 10, LT - 53361 Akademija, Kaunas, Lithuania. Ph. (37) 752372. e-mail: daiva.jukneliene@asu.lt, Fields of interest: land-use management, land law.

Diana Orechovaitė, student, Vytautas magnus University, Institute of Land Use Planning and Geomatics, Faculty of Land and Water Management. Address: Universiteto str. 10, LT - 53361 Akademija, Kaunas, Lithuania. Ph. (37)752375. 